\title{
BLUE LIGHT AS AN OCCUPATIONAL HEALTH PROBLEM
}

\author{
Martirosova V. G.', Sorokin V. M.², Nazarenko V. I.', Cherednichenko I. N.', \\ Tikhonova N. N.', Beseda O. Y.'
}

\author{
IState Institution «Kundiiev Institute of Occupational Health of the NAMS of Ukraine», Kyiv \\ 2Lashkarev Institute of Semiconductor Physics of the NAS of Ukraine, Kyiv
}

Introduction. Blue light (BL) covers the region of the short-wave visible radiation $(380-500 \mathrm{n} \mu)$ and has high photon power energy $(2.58-2.75 \mathrm{eV})$ the prolonged exposure to which can cause degenerative phenomena in the retina. The severity of this problem is caused by the anxiety - is it possible to use new high-effective light sources - cold-white LEDs with the color temperature $\left(\mathrm{T}_{\text {color }}\right)$ $4500 \mathrm{~K}$ and higher, due to the presence of BL in its spectrum, which affects the epiphysis of the brain and the pineal gland, producing a melatonin hormone. This can cause an adverse effect on its secretion and on the circadian rhythm in a human. To this date, no physiological studies have been carried out in conditions of a long-term surveillance of the general state of workers in the light environment (LE) with cold-white light sources (CWLS) for substantiation of their use in the lighting systems.

Purpose of the research - to study and evaluate the state of the human body, using indices of the functional state of the visual system on the background of the study of indicators of the cardiovascular and central nervous systems in office workers, performing their tasks in natural conditions within a working day and a working week in the light environment with CWLS at $\mathrm{T}_{\text {color }} 6400 \mathrm{~K}$ under in the uniform lighting of $600 \mathrm{~lx}$. The indices of physiological functions based of the previously conducted studies on the similar contingent of persons who worked about 10 years in conditions with fluorescent lamps (FL) of $500-550 \mathrm{~lx}$ and $\mathrm{T}_{\text {color }} 6200 \mathrm{~K}$ were used as the control.

Materials and research methods. The first stage - computer modeling of photometric parameters according to the program DiaLux for creating a design of the lighting device for the general uniform lighting of $600 \mathrm{~lx}$ with the CWLS and $\mathrm{T}_{\text {color }} 6400 \mathrm{~K}$ in the working room of «The Handling Company of Ukraine» in the city Kiev, in which office employees worked constantly for 8-hours a work day (from 9.00 to 18.00 , with one hour break). At the density of work about $92 \%$, they performed their duties of the medium heaviness (IV category of work, according to the State Building Norms (DBN) (Ukrainian standard) B 2.5-282006. The intensity of nervous-emotional and sensory strain of work corresponded to Class 3.1, by the Hygienic Classification of Work. The second stage - selecting subjects and their training in understanding the tasks. 12 practically healthy persons, aged $28-35$, with the work experience from 5 to 10 years have been selected. The third stage - studies of the potential abilities of the visual system, accommodation-convergent stability with the help of achromatic adisparapia, activity of the nervous processes in the retina with the help of negative sequential contrast (NSC), quantitative and qualitative indices of the static and dynamic visual performance (VP) on the background of research of parameters of the cardiovascular and central nervous systems with the use of Golovin-Sivtsev tables for close distances, Adisparopia device, NSC tables, special test tables, including visometry. A general medical examination was carried out according to the accepted methods. 5 series of studies in the dynamics of a working day over a working week were conducted, in one week, in a month, in 2.5 months and after 4 months of work in the new lighting environment with SWLC and $\mathrm{T}_{\text {color }} 6400 \mathrm{~K}$. Also, a questionnaire was used to assess the subjective perception of the new LE. Results. The data of the studies show an oscillatory character of functions with a small amplitude and gradual increase of their level by the end of the studies throughout the whole period, pointing to the character of adaptive mechanisms to the new light environment. It is established, that the increase in reserves of accommodation from 2,4-2,5 D to 3,66 D ( $p<0,05)$ was recorded in a month. The indices of achromatic adisparopia $(\mathrm{p}<0,05)$ by the time of the initial effect and by the total time of unclear vision after 4 months increased during the whole week of research in comparison with the control. The indices of the short-term memory $(\mathrm{p}<0,05)$ in the first week were increased significantly and highly stabilized at the end of the study. The analysis of parameters of the (VP) $(\mathrm{p}<0,05)$, reflecting the integral state of functions of the eye resolution, contrast sensitivity and speed of differentiation demonstrate their stability over the whole period of research with the increase of the level close by the end, in comparison to the control group (CG). The data of the subjective indicators of the comfort environment with the SWLC and $\left(\mathrm{T}_{\text {color }}\right) 6400 \mathrm{~K}$ showed a high score of $4.3-4.4$ points by the 5-point assessment according to the questionnaire.

Conclusion. On the basis of the analysis of the conducted physiological studies on the radiation influence of the blue-white LED light with $\left(\mathrm{T}_{\text {color }}\right) 6400 \mathrm{~K}$ on the functional state of visual, central nervous and cardiovascular systems in office workers in production conditions it is established, that on the background of the general satisfactory subjective estimation of LE, the oscillatory character of research functions can be traced with a small amplitude and gradual increase of their level and their higher stabilization by the end of the study as compared to the CG. This gives the proof to recommend their usage for the general uniform lighting systems taking into account our recommendations.

Key words: blue light, light environment, cold white LEDs, experimental studies, office workers, physiological studies, visual performance, questionnaires

(C) Колектив авторів, 2019 


\section{Introduction}

Blue light (BL) is a short-wave range of the visible radiation with a wavelength of $380-500 \mathrm{~nm}$ in the range of electromagnetic radiation (EMR). Blue light covers light waves beginning with a violet range (from 380 to $420 \mathrm{~nm}$ ) to the blue one (from 420 to $500 \mathrm{~nm}$ ).

Light waves of the blue range have the shortest length and according to Rayleigh scattering law they are scattering rather intensively. Therefore, a significant part of the irritating shine of the solar radiation is due to the blue light, giving the sky and the ocean its color. Also, blue light scatters in the structures of the eye, causing high aberration, worsening the quality of the visibility for objects of distinction.

For decades, scientists have been carefully studied the influence of blue light on the human body, discussing its positive $[10,18]$ and negative qualities, not coming to a consensus [17].

A profound study of the effect of BL and its hazardous effect (Blue hazard) on humans [1, 2] and a global interest to the problem over the past decade were caused by a wide use of new energy-efficient LED light sources of $420-470 \mathrm{~nm}$ [4, 8, 9, 11, 12], coinciding with the curve of sensitivity of recently discovered new ganglion cells in the retina by American scientist E. Berson in 2002 [15] (Fig. 1).

The new ganglion has a direct connection with the hypothalamus region of the brain and the pineal gland, producing a melatonin hormone, which, in

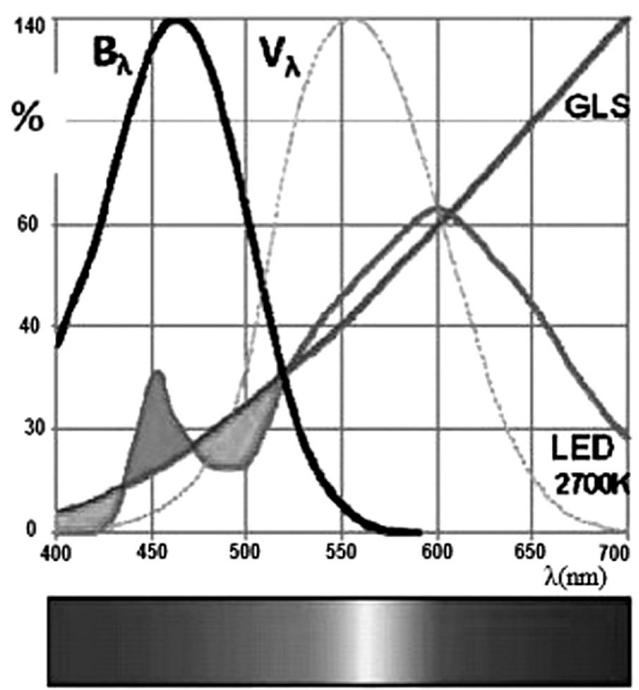

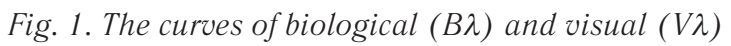
sensitivity of a human in comparison with the spectrum of an incandescent lamp (GLS) and LED $2700 \mathrm{~K}$ (Bommel W., 2010) turn, participates in all endocrine processes of the body, and, most importantly, regulates the circadian rhythm of a human.

The spectral composition of radiation in electronic devices, generating peak radiation of $440 \mathrm{~nm}$ in smart phone screens, TV sets, tablets and computers, emitting $40 \%$ more blue light in comparison with the natural solar radiation is of great concern for specialists.

The International Standardization Organization in its standard 13666 named the blue light wavelength range with a center of $440 \mathrm{~nm}$ as the range of the functional risk for the retina, and these wavelengths of blue light can cause photoretinopathy and MAD (macula age degeneration).

Experiments conducted by Mark Ree, Director of the Center of Light Research in New York, show that an hour exposure to white light-emitting diode can cause decrease of the melatonin level by $3-8 \%$. For comparison: the radiation from a computer screen reduces the level of melatonin by $7-20 \%$.

The use of energy-saving light sources, emitting blue light in the color temperature ranging from $4500 \mathrm{~K}$ and higher, is of the similar concern $[3,13,14,16]$.

Effects of BL. Three important factors should be noted in the etiology of BL:

- Blue light photons have the highest power $2.58-2.75 \mathrm{eV}$, as compared to red ones $-<1.97 \mathrm{eV}$ and green ones $-2.25-2.43 \mathrm{eV}$, which, according to the results of field studies and in experimental conditions, are 15 times more dangerous for the retina than the entire range of the visible light;

- Light waves of the blue range have the shortest length and therefore can intensively scatter in the structures of the eye, causing the decrease in the function of the contrast sensitivity of the eye, worsening the quality of perception of objects and contributes to developing symptoms of the advanced stage of the visual fatigue - asthenopia;

- It has been established that blue light photons are innervated in the sympathetic department of the CNS (Prof. S. V. Kravkov).

Influence of BL. The studies show that the effect of $\mathrm{BL}$ on the visual organ can cause formation of photochemical damages in the retina (particularly in its pigment epithelium and in photoreceptors). In this, the risk of the damage increases exponentially with the increase of the photon energy, resulting in changes in the eye bottom and to similar symptoms of the age macular degeneration (AMD): 
- One of the initial causes of the retinal damage is lipofuscin - a phototoxic pigment which owing to the selective light absorption in the zone of $440-$ $460 \mathrm{~nm}$ generates free radicals, affecting the retinal pigment epithelium;

- Toxic lipofuscin granules are permanently and irreversibly accumulated in the cells of the retinal pigment epithelium, which is one of the main causes of its disease and irreversible vision loss;

- It has been proved that the main factor in the $\mathrm{BL}$ pathogenesis is that a photochemical reaction, which produces free radicals, also causes a damaging action on photoreceptors - cones and sticks;

- Metabolic products developing as a result of the photochemical reaction cannot be normally utilized by the retinal epithelium, so they are accumulated and cause its degeneration;

- The International Organization for Standardization in its standard 13666 [7] named the wavelength range of $440 \mathrm{~nm}$ as the range of the functional risk for the retina. These are wavelengths of BL that cause photoretinopathy and AMD [3, 5]. The main risk group covers 3 categories: 1) children;

2) people with high sensitivity to light, working under bright light; 3) patients with intraocular lenses.

Purpose of the work. The world scientific community has been arguing for decades about harm and benefits of the BL impact on the human body. One of them talk about a serious threat and harmful action of $\mathrm{BL}$, the others give strong arguments in favor of their health effect. In the opinion of some scientists [24, 25 ] the negative impact of BL on humans is greatly exaggerated. It should be noted that all conclusions about the pathogenesis of BL were formulated on the basis of laboratory studies on animals in the exposure to BL from 5 to 7 hours at a distance of $10-15 \mathrm{~cm}$ from the eye [1, 2].

The efficiency and qualities of new LED lamps (mercury-free production, temperature range +45 and -45 , high color rendering index and efficiency, duration of usage, etc.) $[8,9]$ had attracted attention of the developed countries (Germany, England, France, South Korea, USA, etc.), which, in a short period of time (from 1990 to 2002), proposed them for domestic usage and for production facilities, based mainly on the high energy efficiency of the latter, without taking into account light characteristics of SWLC. However, after the discovery of new ganglion cells in the retina in 2002, approaches to their use changed and recommendations are now issued with due account of peculiarities of occupational activity of workers under the color temperature $[3,6]$.

Wide and uncontrolled introduction of new LED light sources in all spheres of production of Ukraine, including kindergartens, higher educational institutions, is made without taking into account color temperatures, forced us to study the impact of SWLC on the human body and to develop recommendations for their use. The spectral characteristics of lamps, used in the experiments, are shown in Fig. 2, from which it is clear that the splash of the blue component in cold white lamps is much higher than in warm-white lamps.

In previous experiments we studied the influence of the color temperature on the workers' body in the comparative aspect in the light environment with cold-white and warm-white LED light sources. In the analysis of the received data, regularities of changes in the functional state of the body of subjects exposed to the light-emitting diode light from lamps with the color temperature $\mathrm{T}_{\text {color }} 4100 \mathrm{~K}$ and $\mathrm{T}_{\text {color }} 6400 \mathrm{~K}$, have been established, pointing to a stimulating character of cold-white lamps and, on the contrary, to a slowing character of warm-white ones (Fig. 3).

The figure shows that with yellow-white lamps, the initially high level of performance decreases rapidly, while with cold-white lamps the performance level gradually increases and reaches its high degree. So far, there have been no long-term studies on the effect of SWLC in the work environment.

\section{Methods and objects of studies}

The main purpose was to organize and conduct physiologo-hygienic study of the effect of light-emitting diodes of warm-white and cold-white light with color temperature $\mathrm{T}_{\text {color }} 6400 \mathrm{~K}$ and $4100 \mathrm{~K}$ on the visual, cardiovascular and central nervous systems of subjects in the laboratorial and working conditions.

First stage: computer modeling of photometric parameters by the DiaLux program, mounting the lighting system on the ceiling of the experimental laboratory in the premises of the «Handling Company of Ukraine», where office workers wre engaged in the work during an eight hour working day (from 9.00 to 18.00 with one hour break) with $92 \%$ work density. The visual work of the average hardness (fourth category) was performed in the uniform lighting of $600 \mathrm{~lx}$ 
ISSN 2223-6775, Ukrainian Journal of Occupational Health, 2019, 15 (3), 194-203
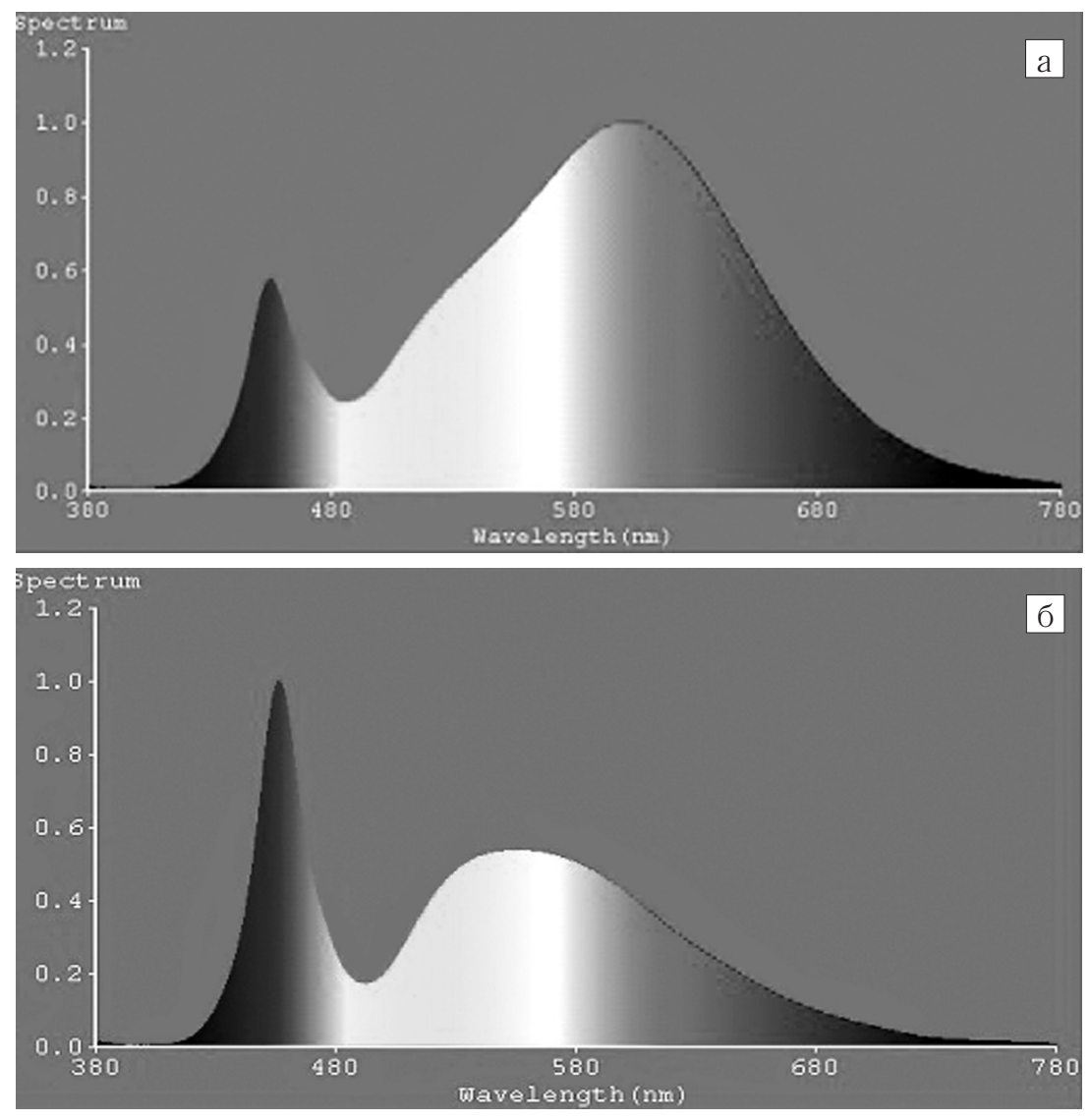

Fig. 2. Spectral characteristics of LED light sources with color temperature:

a) $4100 \mathrm{~K}$; b) $6400 \mathrm{~K}$

(according to DBN B.2.5-28-2006 (Ukrainian standard) [20].

The work of office workers corresponded to Class 3.1 according to nervous-emotional strain and sensory loads by the Hygienic Classification of Work [21].

The second stage: selection of subjects from 34 persons and defining their ability to the applied methods. 12 practically healthy individuals, aged $28-35$, with normal visual function and the work experience of $6-10$ years have been selected.

The third stage - a series of four physiological studies over the working day in a working week were conducted, in one week, in a month, in 2,5 months and after 4 months with SWLC of $\mathrm{T}_{\text {color }} 6400 \mathrm{~K}$ and $600 \mathrm{~lx}$ lighting. A combination of physiological and psychophysiological methods was used to assess the influence

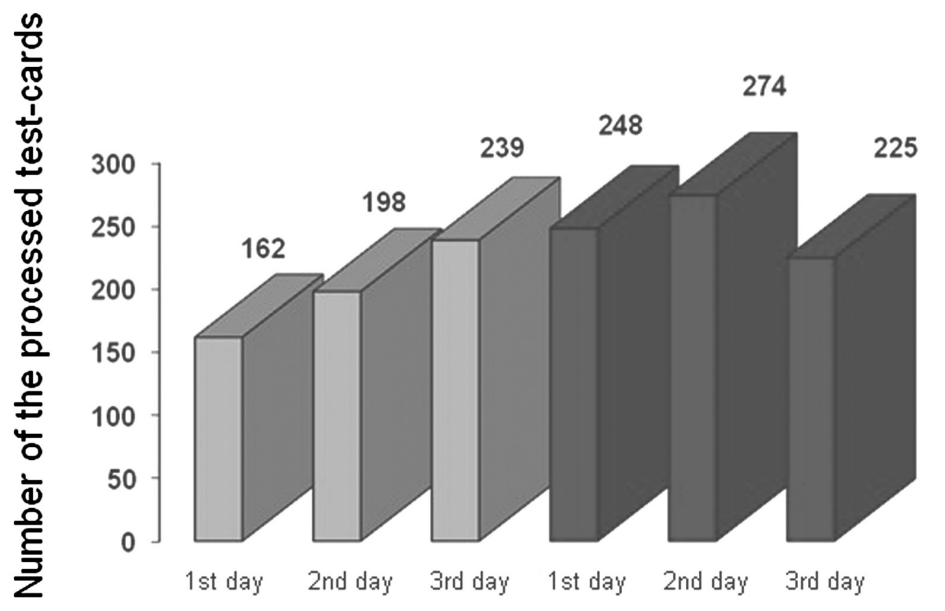

LED 7900

\section{LED 4000}

Fig. 3. Comparative characteristics of visual performance in the work with LED light sources of $6400 \mathrm{~K}$ and $4100 \mathrm{~K}$ 
of the cold-white SWLC on the functional state of the visual system, the activity of excitation processes in the muscular and photosensitive apparatuses of the eye, as well as the quality of information transfer to the central department of the visual system, to primary and secondary visual centers [19]. There have studied: visometry, potential abilities of the visual system, accommodation-convergent stability with the help of achromatic adisparapia, negative sequential contrast, quantitative and qualitative parameters of static and dynamic visual performance on the background of the research of parameters of cardiovascular and central nervous systems, using Golovin-Sivtsev tables for close distances, Adysparopia test, NSC tables, specially developed tables with the Landolt rings. Medical examinations were conducted by institution's doctors by rutine methods, eye biomicroscopy with a slit lamp.

The indices of the experimental studies on the same contingent of office workers in the dynamics of the working day and during a working week, with the work experience of 5-10 years in the light environment with fluorescent lamps with $\mathrm{T}_{\text {color }} 6200 \mathrm{~K}$ and 550 lx lighting were used as the control.

Experimental physiological studies of the functional state of the body of office workers in conditions of LED lighting with $T_{\text {color }} 6400 \mathrm{~K}$. Considering the data of physiological studies it is seen, that almost all investigated functions of some main systems of the body are of an unidirectional character, appeared by fluctuation of the level of functions with different amplitudes and equalizing by the end of $4^{\text {th }}$ month of the study with the level, exceeding in the control group indicators at work with luminescent lighting.

Studies of the parameters of the absolute negative reserves of accommodation $(p<0,05)$, which deter- mine the potential ability of the eye, have established their fluctuating character. At the same time, they slightly decrease at weekly and monthly work efficiency, then increase after 2,5 months ( $p<0,05$ ) and stabilize after 4 months of dynamic observations in comparison with the control group. The analysis of the indicators of achromatic adisparopia ( $\mathrm{p}<$ 0,05 ) shows that both by the time of the primary effect of adisparopia and by the total time of unclear vision in the two-minute exposure of the object during a week and after 2,5-month work, the level of adaptation decreases, and after 4 months of work in the new conditions it increases throughout the working day.

Fig. 4, 5, 6 show graphs of visual performance and the state of the central nervous system in the subjects.

Fig. 4 shows that the error rate has a character of a small range fluctuation and after a month of work it is traced the tendency to its increase, maintaining throughout the period of observation. Approximately of the same type is the curve of the short-term memory, presented in Fig. 5.

After four months the improvement of the quality of work is seen and the decrease in the number of errors as compared to the control group.

Figure 6 shows the data of the integral (quantitative and qualitative indicators) visual performance, reflecting the state of the main functions of the visual system- contrast sensitivity of the eye, visual acuity of the eye and the speed of differentiation.

It is seen, that when performing complicated test tasks (object of differentiation - 0,01) in conditions of the given lighting environment with the cold-white SWLC phase fluctuations of indicators of the visual performance with a gradual increase and stabilization

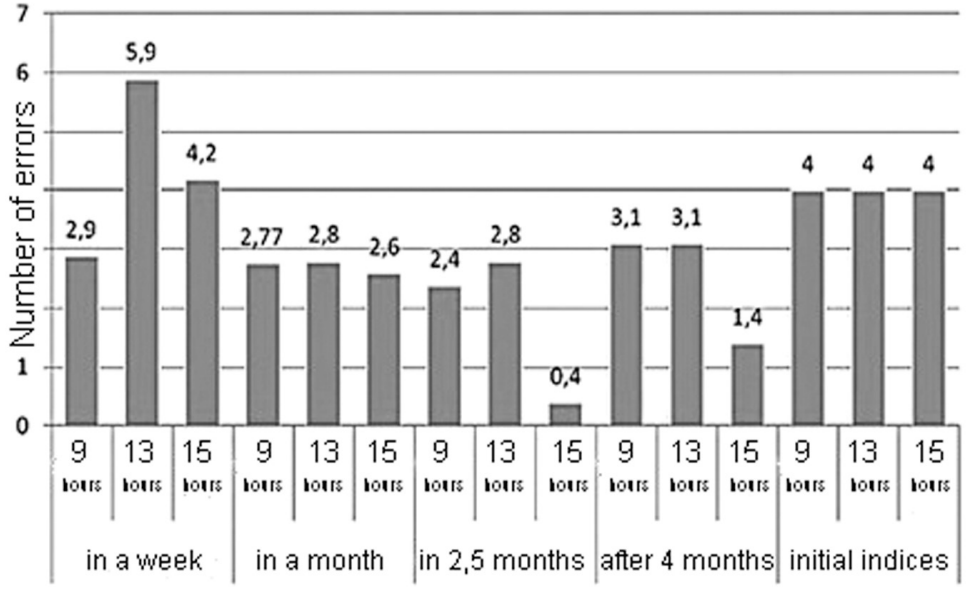

Fig. 4. Qualitative indicators of the visual performance in the dynamics of a working day and a working week in a 4 month study 

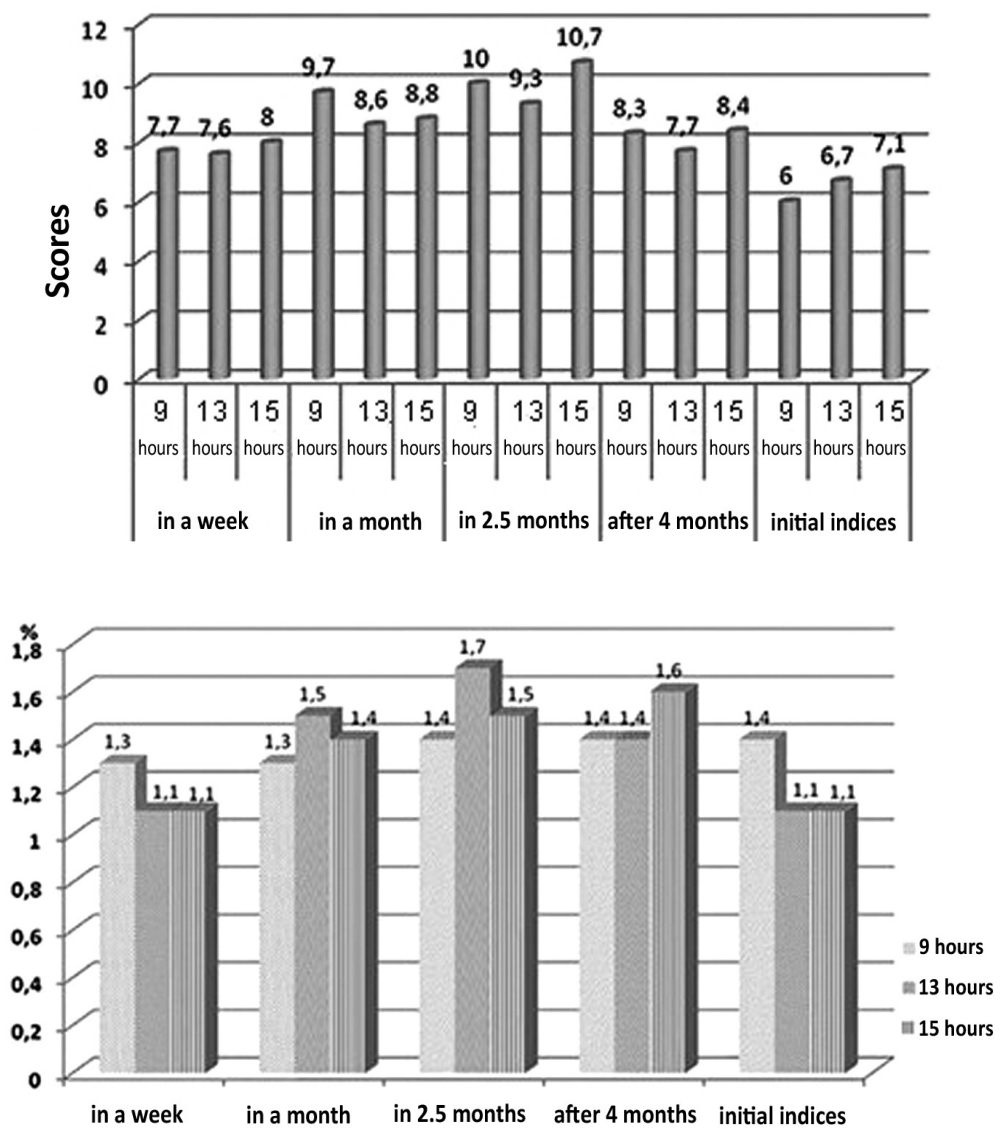

Fig. 5. Indices of the short-term memory in the study period
Fig. 6. Integral indices of the visual performance of its level by the end of 4 months of studies with the level, exceeding indications of the control group, are occurred.

At the same time, indicators of the subjective assessment of the lighting conditions were recorded in the dynamics of the working day using questionnaires, and blood pressure and heart rate were measured (Table).

As can be seen in the table, which shows subjective indicators of the comfort of work conditions with LED lighting and its psycho-emotional perception by workers over 4 months of work under $\mathrm{T}_{\text {color }} 6400 \mathrm{~K}$, participants of the study highly appreciate the comfort of lighting $-4,3-4,4$ scores by the 5 -point scale. At the same time, the assessment of the lighting spectrum corresponded to $3,1-3,8$ scores, and the subjective perception of illumination $-3,5-3,8$ scores. The complexity of the visual work was assessed as 2,83-3,6 scores, pointing to the increased strain of work in offices.

Thus, our study of changes in the functional state of visual, cardiovascular and central nervous systems in office workers, exposed to LED light with the color temperature of $6400 \mathrm{~K}$, containing a significant component of blue light (380-480 nm), point to the availability of the complicated processes in the body adaptation, which are stabilizing with high levels to the $4^{\text {th }}$ month of the occupational exposure.

\section{Conclusion}

1. On the basis of the results of the study on the effect of the cold-white visible radiation of SWLC with $6400 \mathrm{~K}$ color temperature and lighting level of $600 \mathrm{~lx}$ on the functional state of visual, central nervous and cardiovascular systems a phase fluctuation of the level of functions of the studied systems with a small amplitude of shifts during the whole period of the studies ( 4 months) was recorded, which were aligned and stabilized by the end of the study (as compared to the control group), indicating the peculiarities of adaptation mechanisms which provide adaptation to new lighting conditions with SWLC. 
Subjective assessment of the light environment and functional indices of CVS in office workers during a work shift $(X \pm m)$

\begin{tabular}{|c|c|c|c|c|}
\hline \multirow{2}{*}{$\begin{array}{l}\text { Duration of exposure } \\
\text { (months) }\end{array}$} & \multirow[b]{2}{*}{ Index } & \multicolumn{3}{|c|}{ Time for a study } \\
\hline & & $\begin{array}{l}9-00 \\
\text { (I) }\end{array}$ & $\begin{array}{c}\text { 13-00 } \\
\text { (II) }\end{array}$ & $\begin{array}{l}\text { 17-00 } \\
\text { (III) }\end{array}$ \\
\hline \multirow{5}{*}{$1^{\text {st }}$ month } & CL, scores & $4,20 \pm 0,18$ & $4,30 \pm 0,19$ & $4,30 \pm 0,18$ \\
\hline & CVW, scores & $2,80 \pm 0,52$ & $3,30 \pm 0,36$ & $3,0 \pm 0,38$ \\
\hline & ASL, scores & $3,30 \pm 0,18$ & $3,30 \pm 0,19$ & $3,80 \pm 0,18$ \\
\hline & SPL, scores & $3,50 \pm 0,35$ & $3,70 \pm 0,20$ & $3,50 \pm 0,19$ \\
\hline & Health, scores & $3,50 \pm 0,35$ & $3,0 \pm 0,32$ & $2,50 \pm 0,19$ \\
\hline \multirow{5}{*}{ 2,5 months } & CL, scores & $4,40 \pm 0,16$ & $4,0 \pm 0,21$ & $4,20 \pm 0,15$ \\
\hline & CVW, scores & $2,80 \pm 0,39$ & $2,80 \pm 0,36$ & $2,80 \pm 0,35$ \\
\hline & ASL, scores & $3,20 \pm 0,14$ & $3,20 \pm 0,15$ & $3,20 \pm 0,28$ \\
\hline & SPL, scores & $3,80 \pm 0,29$ & $3,30 \pm 0,19$ & $3,80 \pm 0,28$ \\
\hline & Health, scores & $3,40 \pm 0,31$ & $3,20 \pm 0,16$ & $2,50 \pm 0,31$ \\
\hline \multirow{5}{*}{4 months } & CL, scores & $4,30 \pm 0,18$ & $3,80 \pm 0,27$ & $3,90 \pm 0,26$ \\
\hline & CVW, scores & $3,60 \pm 0,20$ & $3,50 \pm 0,21$ & $3,60 \pm 0,20$ \\
\hline & ASL, scores & $2,70 \pm 0,28$ & $3,20 \pm 0,16$ & $3,0 \pm 0,22$ \\
\hline & SPL, scores & $3,40 \pm 0,19$ & $3,30 \pm 0,16$ & $3,30 \pm 0,28$ \\
\hline & Health, scores & $3,70 \pm 0,18$ & $2,70 \pm 0,19$ & $2,60 \pm 0,39$ \\
\hline
\end{tabular}

2. The results of studies, based on the survey of office workers, demonstrate that one of the factors limiting working capacity is the light environment.

3. The optimal level of light plays a major role in formation of the subjective perception of comfort at work, whereas the color temperature plays a secondary role in human perception of light.

4. Taking into account the positive subjective perception of comfort in the light environment with coldwhite CWLS and their ability to stimulate work capacity we can recommend to use them in work conditions with lamps with matte light scatters, providing the general uniform lighting [22, 23].

\section{Preventive measures}

1. People working with electronic devices should follow work and rest schedules in accordance with the

\section{References}

1. Ostrovsky M. A. (2005), «Molecular mechanisms of the damaging effect of light on the eye structures and ways of protection from such damages", Uspekhi biologicheskoi khimii, 54, 173-204.

2. Zak P. P., Ostrovsky M. A. (2012), «Potential hazard from lighting with light diodes for children and adolescents", Svetotekhnika, 3, 4-7. current legislation, provided with yellow filters with the coefficient of light reflection for screens $0,7 \%$

2 . The lighting of working premises should be provided by a system of the general uniform lighting with $600 \mathrm{~lx}$ at workplace.

3. In the development and mounting a lighting system with SWLC, in order to reduce glare and blinding, causing depletion of the working capacity of the eye, it is desirable to take into account the direction of the light flux to the upper hemisphere.

4. SWLC lamps should be equipped with light scatters for decreasing brightness not exceeding $5000 \mathrm{~cd} / \mathrm{m}^{2}$ and a protective angle of no less than $90^{\circ}$, to provide the diffuse and uniform light environment.

5. It is recommended to use glasses with a special covering to protect eyes from the dangerous blueviolet light.

3. Behar-Cohen F., Martinson C., Vienot F. et al. (2011), "Light-emitting diodes (LED) for domestic lighting: any risks for the eye?», Prog. Reton. Eye Res., 30 (4), 239-257. https://doi.org/10.1016/j.preteyeres.2011.04.002.

4. Dehoff P. (2012), «Quality of light and energy efficiency does not contradict each other", Svetotekhnika, 3, 64-68.

5. DSTU EN 12464-1 (2016), Svitlo ta osvitlennya. Osvitlennya robochykh mists. Chast 1 . Vnutrishni robo- 
ISSN 2223-6775, Ukrainian Journal of Occupational Health, 2019, 15 (3), 194-203

chi mistsya (EN 12464-1:2011) [Light and lighting. Lighting of workplaces. Indoor work places], Kyiv, Ukraine.

6. Gorbunov A. I., Smirnov A. V. (2015), «Improvement of the criteria and methods of assessment of work conditions at workplaces", Materials of the International Conference, Bernardovskiye chtenia [Bernard readings], 279-282.

7. ISO 13666.

8. Martirosova V. G., Nazarenko V. I., Sorokin V. M., Galinsky A. D. (2011), "Physiological and hygienic evaluation of radiation of light emitted diode sources of light", Ukrainian Journal of Occupational Health, 2 (26), 27-35.

9. Martirosova V. G., Nazarenko V. A., Sorokin V. M., Galinsky A. D. (2011), "Hygienic aspects of LED light use at enterprise of Ukraine", Svitlo-lux, 28 (4), 18-22.

10. Zakheim A. L. (202), "LED systems of lighting: energy efficiency, visual perception, safety for the health", Svetotekhnika, 6, 2020-24.

11. Martirosova V. G., Nazarenko V. I., Sorokin V. M., Galinsky A. D. (2012), "Physiologo-hygienic assessment of LED lighting in conditions of the production experiment", Svitlo-lux, 3, 43-49.

12. Matrirosova V. G., Nazarenko V. I., Sorokin V. M., Galinsky A. D. (2011), "Studies of the effect of LED radiation on some main body functions", Svitlo-lux, 2, 42-47.

13. Martirosova V. G. (2014), "Medical studies of LED radiation on the human body", Promyslova elektroenergetyka ta elektrotekhnyka, 4, 10-20.

14. Martirosova V. G., Koszushko G. P. (2019), "The state of the physiological functions of some main body systems in the work of different duration in light conditions with LED light sources", Promyslova elektroenergetyka ta elektrotekhnyka, 2, 18-23.

15. Berson D. M., Dunn F. A., Takao M. (2002), "Phototransinducation by retinal ganglion calle that set the circadian clock", Science, 295 (5557), 1070-1073. https://doi.org/10.1126/science.1067262.
16. Voitysyak Ts. L. (2013), «Biological effect of lighting traditional and LED", Svetotekhnika, 2, 17-19.

17. Bartsev L. A., Belyaev R. I., Stolyarevskaya R. I. (2013), "Method of measuring of physiologically active brightness of the hazardous blue light from lighting devices», Svetotekhnika, 2, 27-29.

18. Martirosova V. G. (2015), "Influence of LED lighting on melatonin level in the human body", Promyslova elektroenergetyka ta elektrotekhnyka, 92 (2), 35-39.

19. Shamshinova A. M., Volkov V. V. (1999), Funkstionalnye metody issledovaniya $\mathrm{v}$ oftalmologii [Functional methods of studies in ophthalmology], Meditsina, Moscow, Russia.

20. DBN B. 2.5.-28-2006 (State building norms) Pryrodne i shtuchne osvitlennya [Natural and artificial lighting], Ministry of architecture of Ukraine, Kyiv, Ukraine.

21. Hygienic Classification of Work. Hygienic regulations 3.3.5.-8-6.6-083-2001, Ministry of Health of Ukraine, Kyiv, Ukraine.

22. Martirosova V. G., Tereschenko P. S., Beseda O. Yu., Smirnova N. S. (2015), Normalization of quantitative and qualitative parameters of lighting developed by LED at workplaces in offices, Informatsiinyi lyst [Newsletter] № 367, Kyiv, Ukraine.

23. Martirosova V. G., Kozhushko G. M., Smirnova N. S. (2019), Normalization of quantitative and qualitative parameters of lighting developed by LED for premises of general education institutions, Informatsiinyi lyst [Newsletter] № 41, Kyiv, Ukraine.

24. Bilund L. O. (2011), About the paper by E. V. Dolin "Comparative hygienic assessment of conditions of lighting with luminescent lamps and LED", Svetotekhnika, 1, 48-53.

25. Adrian V. (2008), "Comments to the spectrum of light for regulation of melatonin secretion", Svetotekhnika, $1,39-41$.

\title{
Мартіросова В. Г.', Сорокін В. М.², Назаренко В. І·', Черелніченкко І. М.', Тихонова Н. С.', Бесела О. Ю.' СИНЕ СвITАО - ПРОБАЕМА МЕАИUИНИ ПРАU
}

\author{
`Аержавна установа «Інститут медишини праші імені Ю. І. Кундієва Нашіональної академії медичних наук \\ України», м. Київ \\ ${ }^{2}$ Інститут фізики напівпровіАників ім. В. Є. ^ашкарьова Нашіональної академії наук України, м. Київ
}

Bcmyn. Синє світло (СС) займає область короткохвильового видимого випромінювання (380-480 нм) і має енергію високої потужності фотона (2,58-2,75 еВ), тривалий вплив якої може привести до формування дегенеративних явищ у сітківці ока. Гострота цієї проблеми викликана тривогою: чи можна використовувати нові високоефективні джерела світла холодно-білі світлодіоди (СД) з колірною температурою $\left(\mathrm{T}_{\text {кол. }}\right.$ ) від $4500 \mathrm{~K}$ і вище несприятливого впливу на секрецію й циркадний ритм людини. Дотепер фізіологічні дослідження в умовах тривалих спостережень за загальним станом працюючих у світловому середовищі (СВС), обладнаному світильниками з холодно-білими джерелами світла (СДІС) для обгрунтування їхнього застосування в системах освітлення не проводилися.

Мета дослідження - вивчити і оцінити стан організму людини за показниками функціонального стану зорової системи на тлі дослідження даних серцево-судинної і центральної нервової системи у офісних працівників, при тривалому спостереженні на виробництві в природних умовах виконання ними завдань у динаміці робочого дня і протягом робочого тижня в світловому середовищі з СДІС, при Т кол. $6400 \mathrm{~K}$. Контроль склали показники фізіологічних функцій на підставі попередньо проведених досліджень у того самого контингенту осіб, які працювали впродовж 10 років в умовах люмінесцентних ламп (ЛЛ) з рівнем освітленості 500-550 лк і $\mathrm{T}_{\text {кол. }}-6200 \mathrm{~K}$.

Матеріали та методи дослідження. Перший етап - комп'ютерне моделювання фотометричних параметрів у програмі DiaLux, для створення конструкції освітлювальної установки з холодно-білими СДІС і з Т кол. 6400 К, що забезпечує 
загальне рівномірне освітлення в 600 лк, встановленої в робочому приміщенні Хендлінгової компанії України в м. Києві. У примішенні постійно працювали офісні службовці протягом 8-год робочого дня (3 9.00 до18.00 з перервою на 1 год). При щільності праці 92 \% виконувалися роботи середньої тяжкості - IV ступеня, згідно з ДБН В.2.5-282006. Напруженість праці з нервово-емоційної напруги і сенсорних навантажень відповідала класу 3.1, згідно з гігієнічною класифікацією праці. Другий етап - підбір і визначеність працівників до застосовуваних методик. Були відібрані 12 практично здорових осіб у віці 28-35 років зі стажем роботи від 5 до 10 років. Третій етап - проведення дослідження із застосуванням комплексу експрес-методів: візометрія, потенційні можливості зорової системи, акомодаційно-конвергентна стійкість за допомогою ахроматичної адиспаропії, активність нервових процесів у сітківці за допомогою негативного послідовного контрасту (ОПК), кількісні та якісні показники статичної та динамічної зорової працездатності (ЗР) на тлі досліджень показників серцево-судинної та центральної нервової систем з використанням таблиць Головіна-Сивцева для близької відстані, приладу для адиспаропії, таблиць для ОПК, спеціальних тестових таблиць і ін. Медичний огляд проведено за загально прийнятими методиками. Проведено 5 серій досліджень у динаміці робочого дня протягом робочого тижня, через тиждень, через 1 місяць, 2,5 місяця і через 4 місяці роботи в умовах нового світлового середовища з СДІС за колірної температури $\mathrm{T}_{\text {кол. }}=6400 \mathrm{~K}$ і освітленості $\mathrm{E}=600$ лк. Паралельно проведено анкетування для оцінки суб’єктивного сприйняття нової СВС.

Результати. Дані досліджень показали коливальний характер функцій з невеликою амплітудою та поступовим невеликим підвищенням їхнього рівня протягом усього періоду й до кінця досліджень, що свідчить про характер пристосувальних механізмів до нового світлового середовища. Встановлено, що через 1 місяць роботи спостерігається підвищення резервів акомодації з 2,4-2,5Д до 3,66 Д (p < 0,05). Показники ахроматичної адиспаропії $(\mathrm{p}>0,05)$ за часом первинного ефекту і за сумарним часом неясного бачення підвищуються через 4 місяці порівняно 3 контролем. Показники короткочасної пам'яті $(\mathrm{p}<0,05)$ з першого тижня значно підвищилися $\mathrm{i}$ до кінця досліджень стабілізувалися на високому рівні. Аналіз показників ЗР $(\mathrm{p}<0,05)$, що відображають інтегральний стан функцій розподільної здатності ока, контрастної чутливості та швидкості розрізнення, свідчить про їхню стійкість протягом усього періоду досліджень з підвищенням рівня до кінця досліджень порівняно з КГ. Дані суб'єктивних показників оцінки комфортності світлового середовища при анкетуванні показали високу оцінку - 4,3-4,4 бала за 5-бальною шкалою.

Висновки. На підставі аналізу проведених фізіологічних досліджень впливу випромінювання холодно-білого світла світлодіодних світильників з $\mathrm{T}_{\text {кол. }} 6400 \mathrm{~K}$ у виробничих умовах на функціональний стан зорової, центральної нервової і серцево-судинної систем у офісних працівників встановлено, що на тлі загальної задовільної суб'єктивної оцінки СВС простежується коливальний характер досліджених функцій з невеликою амплітудою і поступове підвищення їхнього рівня з стабілізацією до кінця досліджень на більш високому рівні порівняно з КГ, що дає можливість рекомендувати застосування світлодіодних джерел світла в системах загального рівномірного освітлення 3 урахуванням розроблених нами рекомендацій.

Ключові слова: синє світло, світлове середовище, холодно-білі світлодіоди, експериментальні дослідження, офісні працівники, фізіологічні дослідження, зорова працездатність, анкетування

\title{
Мартиросова В. Г.', Сорокин В. М.' ${ }^{2}$, Назаренко В. И.', Чередниченко И. Н.', Тихонова Н. С.', БесеАа А. Ю.' СИНИЙ СВЕТ - ПРОБЛЕМА МЕАИUИНЫ ТРУАА
}

\author{
'Государственное учрежАение «Институт медицины труда имени Ю. И. Кундиева Национальной академии \\ медицинских наук Украины", г. Киев
}

\section{${ }^{2}$ Институт физики полупроводников им. В. Е. Аашкарева Национальной акацемии наук Украины, г. Киев}

Вступление. Синий свет (СС) занимает область коротковолнового видимого излучения (380-480 нм) и обладает энергией высокой мощности фотона (2,58-2,75 еВ), длительное воздействие которой может привести к формированию дегенеративных явлений в сетчатке глаза. Острота этой проблемы вызвана тревогой: можно ли использовать новые высокоэффективные источники света -холодно-белые светодиоды $(С Д)$ с цветовой температурой $\left(\mathrm{T}_{\text {шв }}\right)$ от $4500 \mathrm{~K}$ и выше в связи с наличием в их спектре СС, который воздействует на эпифиз мозга и шишковидную железу, вырабатывающую гормон мелатонин, что может привести к неблагоприятному влиянию на ее секрецию и циркадный ритм человека. До настоящего времени физиологические исследования в условиях длительных наблюдений за общим состоянием у работающих при световой среде (СВC), оборудованной светильниками с холоднобелыми источниками света (СДИС) для обоснования их применения в системах освещения не проводились.

Цель исследования - изучить и оценить состояние организма человека по показателям функционального состояния зрительной системы на фоне исследования данных сердечно-сосудистой и центральной нервной системы у офисных работников, при длительном наблюдении на производстве в естественных условиях выполнения ими заданий в динамике рабочего дня и на протяжении рабочей недели в световой среде, обустроенной СДИС, при $\mathrm{T}_{\text {цв }} 6400 \mathrm{~K}$, создающей общее равномерное освещение с уровнем 600 лк. Контроль составили показатели физиологических функций на основании предварительно проведенных исследований у того же контингента лиц, проработавших в течение 10 лет в условиях люминесцентных ламп (ЛЛ) с уровнем освещенности 500-550лк и $\mathrm{T}_{\text {цв }}-6200 \mathrm{~K}$.

Материалы и методы исследования. Первый этап - компьютерное моделирование фотометрических параметров в программе DiaLux для создания конструкции осветительной установки с холодно-белыми СДИС с $\mathrm{T}_{\text {цв }} 6400 \mathrm{~K}$, обе- 
ISSN 2223-6775, Ukrainian Journal of Occupational Health, 2019, 15 (3), 194-203

спечивающей общее равномерное освещение в 600 лк, установленной в рабочем помещении Хендлинговой компании Украины в г. Киеве. В помещении постоянно в течение 8-ч рабочего дня (с 9.00 до18.00 с перерывом 1 ч) трудились офисные служащие. При плотности работы $92 \%$ выполнялись работы средней тяжести - IV разряд работ согласно ДБН В.2.5-28-2006. Напряженность труда по нервно-эмоциональному напряжению и сенсорным нагрузкам соответствовала классу 3.1 согласно гигиенической классификации труда. Второй этап - подбор и подготовленность испытуемых к применяемым методикам. Были отобраны 12 практически здоровых лиц в возрасте 28-35 лет со стажем работы от 5 до 10 лет. Третий этап - проведение исследований с применением комплекса экспресс-методов: визометрия, потенциальные способности зрительной системы, аккомодационно-конвергентная устойчивость с помощью ахроматической адиспаропии, активность нервных процессов в сетчатке с помощью отрицательного последовательного контраста (ОПК), количественные и качественные показатели статической и динамической зрительной работоспособности (ЗР) на фоне исследования показателей сердечно-сосудистой и центральной нервной систем при использовании таблиц Головина - Сивцева для близи, прибора для адиспаропии, таблиц для ОПК, специальных тестовых таблиц и др. Медицинский осмотр проведен по общепринятым методикам. Проведено 5 серий исследований в динамике рабочего дня на протяжении рабочей недели, через неделю, через 1 месяц, 2,5 месяца и через 4 месяца работы в условиях новой световой среды с СДИС при цветовой температуре $\mathrm{T}_{ц в}=6400 \mathrm{~K}$ и освещенности $\mathrm{E}=600$ лк. Параллельно проведено анкетирование для оценки субъективного восприятия новой СВС.

Результаты. Данные исследований показали колебательный характер функций с небольшой амплитудой и постепенным небольшим повышением их уровня на протяжении всего периода и к концу исследований, что свидетельствует о характере приспособительных механизмов к новой световой среде. Установлено, что через 1 месяц работы наблюдается повышение резервов аккомодации с 2,4-2,5 Д до 3,66 Д (p < 0,05). Показатели ахроматической адиспаропии $(\mathrm{p}>0,05)$ по времени первичного эффекта и по суммарному времени неясного видения повышаются через 4 месяца по сравнению с контролем. Показатели кратковременной памяти $(\mathrm{p}<0,05)$ с первой недели значительно повысились и к концу исследований стабилизировались на высоком уровне. Анализ показателей 3Р (р < 0,05), отражающих интегральное состояние функций разрешающей способности глаза, контрастной чувствительности и быстроты различения, свидетельствует об их устойчивости на протяжении всего периода исследований с повышением уровня к концу исследований по сравнению с КГ. Данные субъективных показателей оценки комфортности световой среды при анкетировании показали высокую оценку - 4,3-4,4 балла по 5-балльной шкале. Bыводы. На основании анализа проведенных физиологических исследований влияния излучения холодно-белого света светодиодных светильников с $\mathrm{T}_{ц в} 6400 \mathrm{~K}$ в производственных условиях у офисных работников на функциональное состояние зрительной, центральной нервной и сердечно-сосудистой систем установлено, что на фоне общей удовлетворительной субъективной оценки СВС прослеживается колебательный характер исследованных функций с небольшой амплитудой и постепенное повышение их уровня с стабилизацией их к концу исследований на более высоком уровне по сравнению с КГ, что дает возможность рекомендовать применение светодиодных источников света в системах общего равномерного освещения с учетом разработанных нами рекомендаций.

Ключевые слова: синий свет, световая среда, холодно-белые светодиоды, экспериментальные исследования, офисные работники, физиологические исследования, зрительная работоспособность, анкетирование

ORCID ID співавторів та їхній вклад у підготовку та написання статті:

Мартіросова В. Г. (ORCID ID 0000-0002-2777-1724) - організація та проведення експериментальних досліджень на виробництві, обробка даних досліджень, формулювання висновків;

Сорокін В. М. - постановка мети дослідження, організація та контроль установки освітлювальних систем на виробництві;

Назаренко В. I. (ORCID ID 0000-0002-5238-4312) - огляд літератури, розробка анкет, обробка матеріалів досліджень, формулювання висновків;

Чередніченко I. M. (ORCID ID 0000-0001-6654-1334) - огляд літератури, проведення досліджень стану сердцевосудинної системи в динаміці експерименту, обробка даних досліджень;

Тихонова Н. C. (ORCID ID 0000-0001-5856-9919) - контроль параметрів світлового середовища в експерименті, проведення анкетування;

Беседа О. Ю. - контроль параметрів мікроклімату в експерименті, проведення анкетування.

Інформація щодо джерел фінансування дослідження: дослідження виконано в рамках теми «Дослідження особливостей формування зорової втоми при роботі із сучасним комп'ютерним обладнанням та обгрунтування профілактичних заходів», № держреєстрації 0119U100451.

Надійшла: 6 липня 2019 р.

Прийнята до друку: 19 серпня 2019 р.

Контактна особа: Мартіросова Віолетта Генріхівна, кандидат медичних наук, провідний науковий співробітник, лабораторія по вивченню і нормуванню фізичних факторів виробничого середовища, ДУ «Інститут медицини праці імені Ю. І. Кундієва НАМНУ», буд. 75, вул. Саксаганського, м. Київ, 01033. Тел.: + 380442896616. Електронна пошта: martirosovavg@ukr.net 